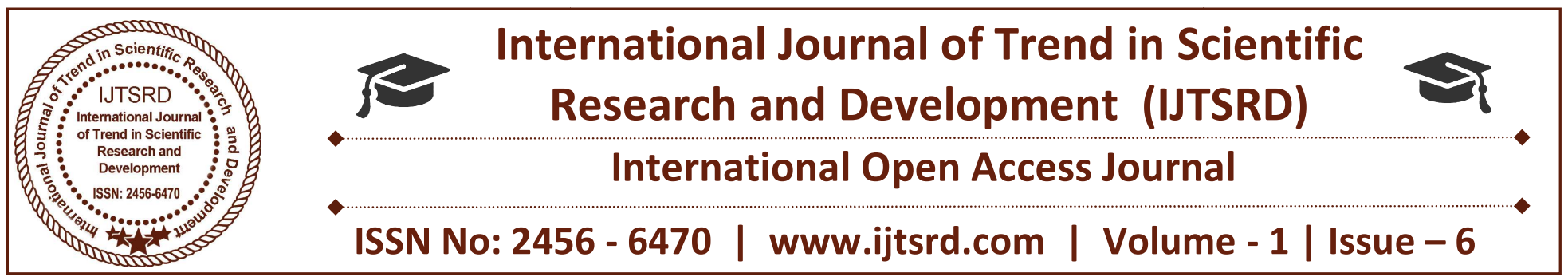

\title{
Towards Scientific Management of Solid Waste through Suitable Landfield Site Selection for Raiganj Municipality West Bengal, India: A Model Based Approach
}

\author{
Bhaswati Roy \\ Research Scholar, Department of Geography, UGB, \\ West Bengal, India
}

\begin{abstract}
Disposal of waste is a fundamental issue of solid waste management process. Now a day suitable landfill site selection is a very difficult process due to rapid urbanization and the interpretative rise of urban population. This paper incorporates with suitable landfill site selection of Raiganj municipality (covering an area of $10.76 \mathrm{~km}^{2}$ ) is located $25^{0} 36$ '59'N to $88^{0} 7$ ' 21 "E of "Raiganj" district sub-division of Utter Dinajpur the least developed districts in West Bengal as well as India with the help of remote sensing \& Global positioning system(GPS) and analysis using geographical information system (GIS). Multi-criteria decision analysis process has been used to find out the suitable site in Arc GIS 10.2.1 version. Various factors such as population density, household density, urban land value, different road types, river, land use, important sites considered in this selecting process and the suitable weighting are imputing to each factors depending upon their relatives importance. Through this way the final solid waste disposal site is indicated for this municipality.
\end{abstract}

Keywords: Solid waste management, Remote sensing and GIS, Multi criteria analysis

\section{INTRODUCTION:}

At present the problem which becomes crucial for our urban society is solid waste and its management due to population explosion, rising economy, booming in community living standards and rapid urbanization (Guerrero et al., 2012; Minghua et al., 2009; Sharholy et al., 2008). As a worldwide problem it is becoming more and more complex day to day (Singha et al., 2011). The term Solid waste management is used as a system for handling all garbage, waste collection, waste storage, waste transfer and transport, processing, recycling programs and disposal of waste in a way that is in balance with the best principal of human health, conservation, economics and environmental considerations (Srivastava et al., 2012). Though solid waste management became a serious issue for every country but it is one of the neglected area of development in India (Dungdung et al., 2012).

As per report of Ministry of Urban development (MoUD) and Pollution Control committees/State Pollution Control Board that in India 1,00,000 MT of Municipal solid waste was generated daily and $1,27,486$ TPD (Tones per day) solid waste is produced during 2011-2012 in our country but only 89,334 TDP $(70 \%)$ of municipal solid waste is collected and 15,881 TPD (12.45\%) is treated or processed out of which (CPCB, 2012).Current population of India is 1.252 billion (2013) and it will continue to grow at the rate $3-3.5 \%$ per year and per capita waste generation increased $1.3 \%$ per year as per solid waste management Manual 2000, annually its increased 5\%. Due to growing amount of solid waste generation and cost effective management process the Government is under presser to effectively and fruitfully handle the solid waste (Rathor et al., 2010).It can be said that in India management of municipal solid waste is going through a carping phase for poor collection, insufficient transportations, unavailability of suitable facilities to disposal and 
treat. Unscientific disposal create unfavourable influence on public health and all others components of environment (Pamnani et al., 2014; Gidde et al., 2008; Sahu et al., 2014; Rathi, 2006; Siddiqui et al., 2013; Rana et al., 2015). So the disposal of municipal solid waste is a one of the central part of solid waste management. Selecting a appropriate solid waste dumping site one of the challenging problems in developing countries due to the lack of proper solid waste management system and waste type thrown to the environment (Mohammedshum et al.2014).Unproper way of disposal creat complex and multidisciplinary difficulty that should be considered from environmental,social and technical as well as ecoomic aspects (Ekmekcioglu et al.2010). The landfill selection is driven by many issues such as availability of land,multipul regions and state regulation, increasing ammount of waste production etc (Gorsevisky et al 2011).

Suitable site selection through geo-spatial analysis is a most important tools to find out suitable location for disposal of urban solid waste. Different scholar's used different methods for disposal site selection (Sener et al 2010 ;Chen, 2014). The multi-criteria decision technique can be used in combination with GIS to arrive at optimal solutions in waste disposal area siting process and it helps to decision maker to ser the priorities and make the best decision by reducing complex evalutions to a series of pair wise comparisons (Suresh \& Sivasankar, 2014). This study was assessing the present status and challenges of waste disposal in Raiganj municipality district town of Utterdinajpur and find out a suitable disposal site with the help of geo-spatial tools. The main objectives of this study are to identify the factors effecting the land fill site allocation and to establish an MCDSS (Multi Criteria Decession Support System) for land fill site suitability in the study area.

\section{Study Area:}

Raiganj municipality is located on the south western part of Uttar Dinajpur district and river Kulik (a tributary of river Nagor) bound from north waste to south east. The town has obtain the municipal status on $15^{\text {th }}$ August 1951 is also known for Raiganj wildlife sanctuary (popularly known as Kulik bird sanctuary). The absolute location of this municipality lies between $88^{0} 6{ }^{\prime} 23.812^{\prime \prime} \mathrm{E}$ to $88^{0} 9^{\prime} 5.932^{\prime \prime} \mathrm{E}$ longitude and $25^{\circ} 38^{\prime} 27.102^{\prime \prime} \mathrm{N}$ to $25^{0} 34^{\prime} 57.153$ 'N latitude.
The area of the municipality is $10.75 \mathrm{sq} \mathrm{km}$ consisting 25 wards (as shown in figure 1) situated $425 \mathrm{~km}$ from the state capital Kolkata. Total population of the area is 183682 out of which 96565 are male and 87092 are female including a rapid growth according to 2011 census record.

The town is considered as a district headquarters of Utter Dinajpur with huge economic growth and urban agglomeration. Many people come here for different purposes, not only from other area of Raiganj block but from its surrounding districts also. Due to such gathering and rapid urbanization a huge amount of solid waste is generated in this town which add trouble to the municipal dwellers. This municipality generated around 97MT waste per day in 2016.There has lack of proper dumping facilities of this area. At present dumping site is located near the river Kulik which degrade the river health and surrounding environment. Considering this entire scenario this study is taking into account for this region.

\section{Figure:1}

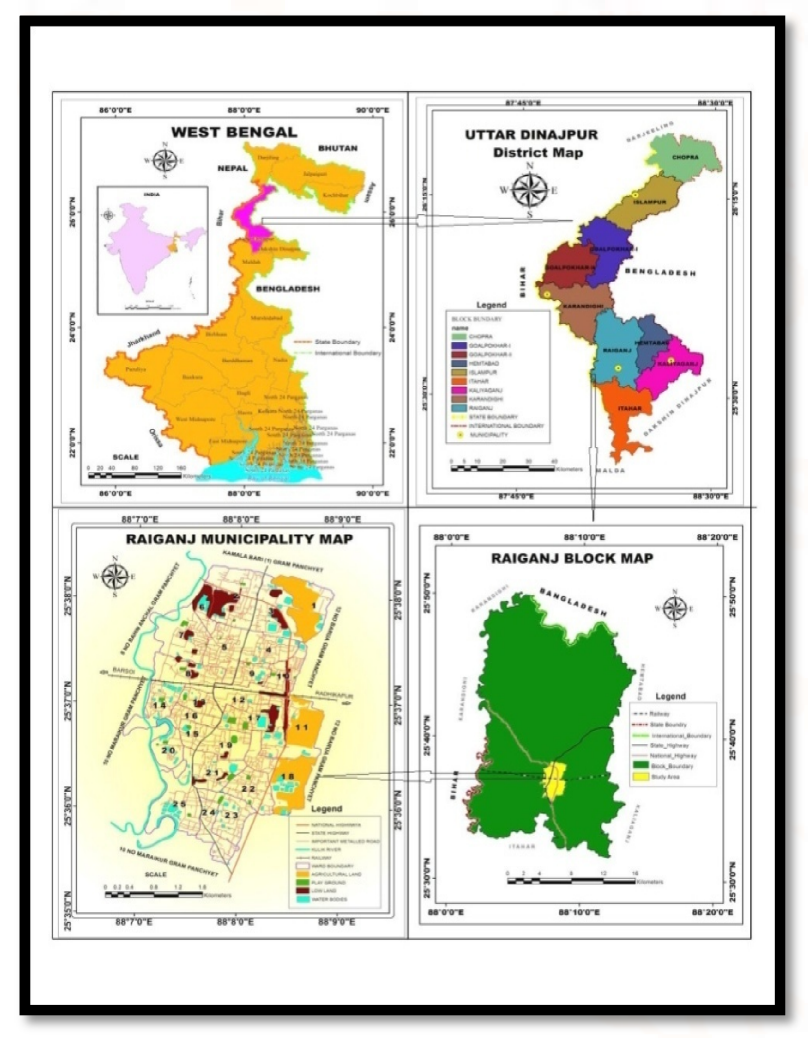

(Location map of study area)

\section{Methodology:}

Two separate cloud-free Landsat digital satellite data of TM5 and OLI/TIRS sensors for the years of 1991 and 2015 covering the study area were acquired freely 
from the U.S. Geological Survey's (USGS) Earth explorer website (http://earthexplorer.usgs.gov/). The Landsat scenes were chosen for this study due to their affordability, availability, and medium to high spatial resolution. Details about the data are given in table 1. Some researchers favor atmospheric corrections of all remote sensing imageries (Gilmore et al, 2015). However, for this study, USGS processed and provided level-one terrain-corrected (L1T) Landsat data in WGS84 geodetic datum, Universal Transverse Mercator map projection (UTM, Zone $45 \mathrm{~N}$ ), and north-up image orientation. According to the Landsat Handbooks of Landsat 5, due to the L1T nature of the data, the radiometric and geometric distortions were already corrected before delivery.

Table: 1 Details of used satellite data

\begin{tabular}{|c|c|c|c|c|c|}
\hline $\begin{array}{c}\text { Name of } \\
\text { Satellite }\end{array}$ & Sensor & $\begin{array}{c}\text { Nos of } \\
\text { Bands }\end{array}$ & $\begin{array}{c}\text { Spectral } \\
\text { Resolution }\end{array}$ & $\begin{array}{c}\text { Spatial } \\
\text { Resolution }\end{array}$ & $\begin{array}{c}\text { Radiometric } \\
\text { Resolution }\end{array}$ \\
\hline Landsat-5 & $\begin{array}{c}\text { Thematic mapper } \\
\text { (TM) }\end{array}$ & 7 & $0.45-2.35 \mu \mathrm{m}$ & $30 \mathrm{~m}$ & 8 -bit \\
\hline
\end{tabular}

\section{Preparation of Land use and Land cover map using digital classification technique}

To work out the land use/cover classification, the hard classification technique vis-à-vis supervised classification method with maximum likelihood algorithm was applied over the FCCs having interband decorrelation of the both years. Maximum likelihood algorithm (MLC) is one of the most popular supervised classification methods used with remote sensing image data. This method is based on the probability that a pixel belongs to a particular class. The basic theory assumes that these probabilities are equal for all classes and that the input bands have normal distributions. This method relies heavily on a normal distribution of the data in each input band and tends to over-classify signatures with relatively large values in the covariance matrix. The spectral distance method calculates the spectral distance between the measurement vector for the candidate pixel and the mean vector for each signature and the equation for classifying by spectral distance is based on the equation for Euclidean distance.

By the means of this classifier algorithm the study area has been segregated in five land use and land cover classes like urban built up area, homestead with plantation, agricultural fallow land, water body and scrubs by assigning per-pixel. Signatures from the corresponding satellite digital data on the basis of the specific Digital Number (DN) value. For each of the predetermined land cover/use type, training samples were selected by delimiting polygons around representative sites. Spectral signatures for the respective land cover types derived from the satellite imagery were recorded by using the pixels enclosed by these polygons. A satisfactory spectral signature is the one ensuring that there is 'minimal confusion' among the land covers to be mapped (Gao and Liu, 2010).

\section{Preparation of other ancillary thematic maps}

For the purposeful fulfillment of the objective of the concerned study different ancillary thematic maps were prepared such as population density map, household density map, urban land value map, important location buffer map, water bodies buffer map, major roads buffer map, national and state highway buffer maps on the basic of both primary and secondary database. It is mention worthy though ware bodies are one of the parameters of LULC; it has been separately parameterized for environmental fraternity. Out of those to visualized the urban expansion which can be treated as main responsible fact for increasing amount of waste generation, The urban area have exacted from LULC of both years and overlaid.

\section{Overlay Analysis}

In this present study weighted overlay analysis method is used to identify the suitable location for disposal site of Raiganj municipality. Weighted overlay is a technique for applying a common measurement scale of value to diverse and dissimilar input to create an integrated analysis (Suresh \& Sivasankar, 2014).Landfill site selection is a complex process which depends upon different environmental and socioeconomic factors. Keepping this view in mind different environmental and socio-economic 
criteria such as population density, household density, urban land value, road network, river, land use and land cover, water bodies, important locations like temple, mosque, college etc are considered in this selection process and the suitable weight age has been assigned to each factor depending upon their relative importance following the rule
$\mathrm{Wij}=(\mathrm{n}-\mathrm{Rj}+1) /\left(\sum \mathrm{n}-\mathrm{Rk}+1\right) \ldots \ldots . .($ Equation$)($ Satty, 1980)

Where, Wij= Weight age, $\mathrm{n}=$ Total no of criteria, $\mathrm{Rk}=$ Rank and $\mathrm{Rj}=$ Intensity of importance. Table (table-2) shows the weightages for municipal waste disposal suitable site.

Table: 2

Weightages assigned to the criterion for waste disposal site suitability

\begin{tabular}{|c|c|c|c|c|c|}
\hline RK & Criteria & $\mathrm{Rj}$ & $\mathrm{n}-\mathrm{Rj}+1$ & $\mathrm{n}-\mathrm{Rk}+1$ & $\mathrm{Wij}$ \\
\hline 1 & Population density & $\mathbf{7}$ & $\mathbf{4}$ & $\mathbf{1 0}$ & $\mathbf{0 . 0 7}$ \\
\hline 2 & Household density & $\mathbf{6}$ & $\mathbf{5}$ & $\mathbf{9}$ & $\mathbf{0 . 0 9}$ \\
\hline 3 & Urban land-value & $\mathbf{1}$ & $\mathbf{1 0}$ & $\mathbf{8}$ & $\mathbf{0 . 1 8}$ \\
\hline 4 & Distance from River & $\mathbf{1 0}$ & $\mathbf{1}$ & $\mathbf{7}$ & $\mathbf{0 . 0 2}$ \\
\hline 5 & Distance from Water-bodies & $\mathbf{9}$ & $\mathbf{2}$ & $\mathbf{6}$ & $\mathbf{0 . 0 4}$ \\
\hline 6 & Distance from National Highway & $\mathbf{2}$ & $\mathbf{9}$ & $\mathbf{5}$ & $\mathbf{0 . 1 6}$ \\
\hline 7 & Distance from State Highway & $\mathbf{3}$ & $\mathbf{8}$ & $\mathbf{4}$ & $\mathbf{0 . 1 5}$ \\
\hline 8 & Distance from Metal road & $\mathbf{4}$ & $\mathbf{7}$ & $\mathbf{3}$ & $\mathbf{0 . 1 3}$ \\
\hline 9 & Distance from sensitive buildings & $\mathbf{5}$ & $\mathbf{6}$ & $\mathbf{2}$ & $\mathbf{0 . 1 1}$ \\
\hline 10 & Land use/Land cover & $\mathbf{8}$ & $\mathbf{3}$ & $\mathbf{1}$ & $\mathbf{0 . 0 5}$ \\
\hline
\end{tabular}

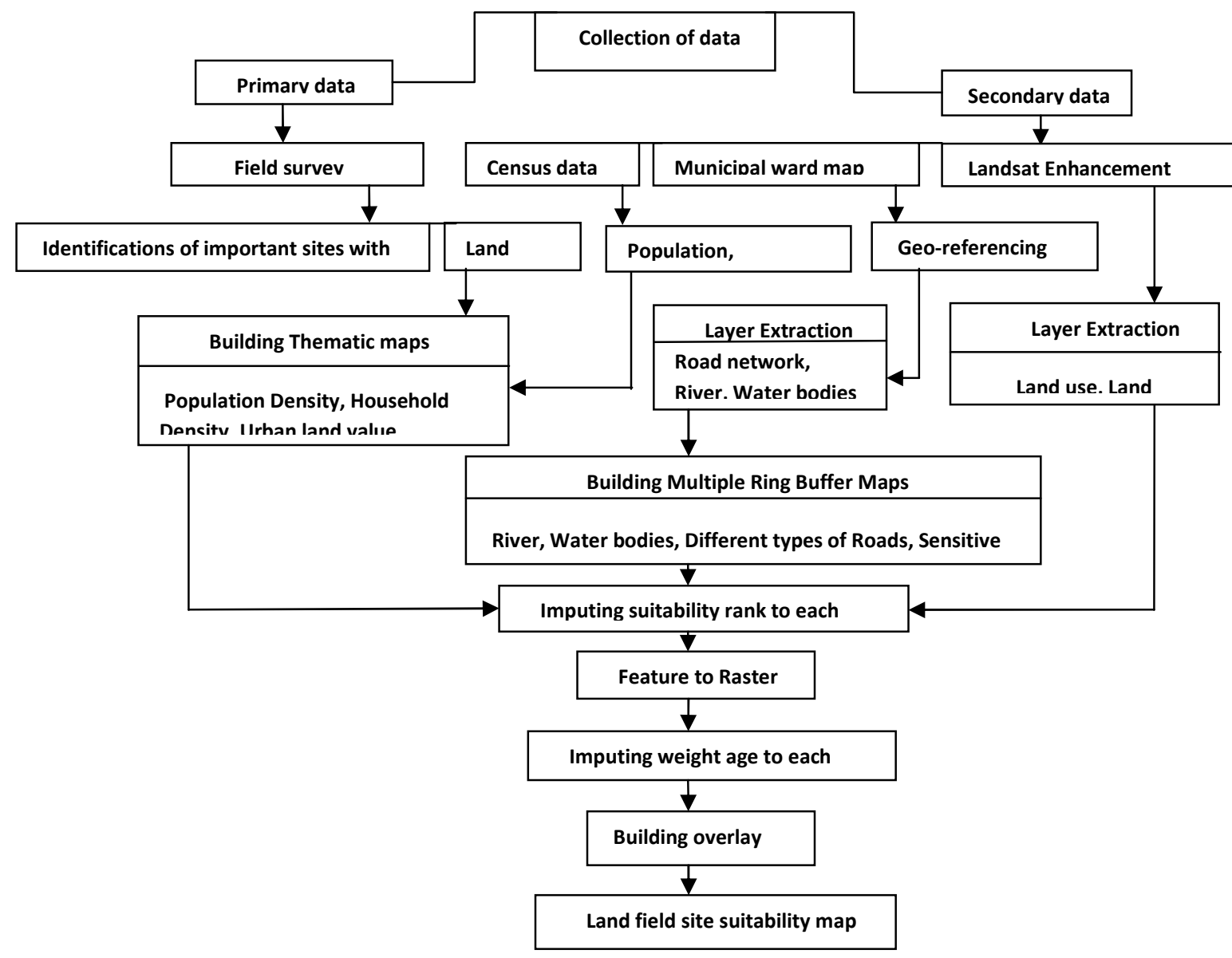




\section{Result and Discussion:}

The positions of land fill sites are dynamic in nature depending on infrastructure. There are three types of criteria that were considered when selecting a land fill site for Raiganj municipality. These are
a) Environmental criteria,
b) Planning criteria
c) Resource criteria.

Each criterion was explained bellow in detailed.

\section{a) Environmental Criteria :}

In this analysis river and waterbodies considered as an environmental criteria.Solid waste disposal site must not be located near river,strems or surface water (Paul, 2012). As per Centeral Polution Control Bord (CPCB) its clearly states that dumping solid waste nearby to river or lake is prohibited.Using Arc GIS tools multiple ring buffer are created from river and water and 1 to 5 score was assigned each buffer ring respectevely (as shown in table $3)$.

\section{b) Planning Criteria :}

Population density,household density,urban land value, important locations, different roads such as state highway, national highway, other metal roads considered as planning criteria.All those creiteria are very imortant prameter for land filled site suitability mesurement.A important location map (fig-4) was devloped with the help of GPS(Global positioning system) survey.Major important sites like temples, mosques, educational institutes, recreation sites etc ware point out.This sites are restricted from development of waste disposal site.A urban landvalue map also prepared through structural interview with different promoters and household.Highest land value in this area is Rs 400000 lakh and lowest land value is Rs 900000 lakh.Highest population density, household density, land value found in the central part of the town mainly ward no $12,13,14$ concidered as a posh area of this municapality.In this study population density 5275-22063 (persons/sq km),household density 1017-4772(houses/sq $\mathrm{km})$, land value Rs.400000-600000lakh are considered as a highest suitable area. The suitability score given for all criterions are given in figure 4 and table 4 respectively.

\section{c) Resource Criteria:}

Land use, land cover map used as a resoures criteria.Disposal site should not be selected near builtup area to avoid adversely effected land value.It should be selected suitable distance from residential area, scrubs land and fallow lands both are most sutable for dumping site
(Jaybbhaye et al,2014).In this analysis landsat-5 image was used for landuse and landcover map enhancement.LULC cassified into five classes such as builtup area,homestread waith plantations, agricultural fallow, water bodies and scrubes which were ranked according there relative importance (as shown in table 4). In this area urban cluster size expending in nature which has impact on LULC and solid waste management also. The various land cover types urban features mainly the built up area shown a dramatic change within this area. It has been increased $11.24 \%$ within 24 years. Significantly negative changes were observed during past 24 years. Agricultural land, water bodies and scrubs transformed into other urban land cover feature and reduced to $-10.68 \%,-2.88 \%$ and $-0.37 \%$ respectively. As shown in figure 3 and table 3 respectively. Rapid urbanization and increasing urban population in the last few years are the main causes of LULC changes in this municipality. The population of town increased from 165045 to 183682 in 1991 and 2011as per census data. This growth of urban population increased demands of land for residential housing. This phenomena increase the town into different direction without following any comprehensive planning guidelines.

\section{Figure 2: Show the landuse/land cover map of Raiganj municipality}

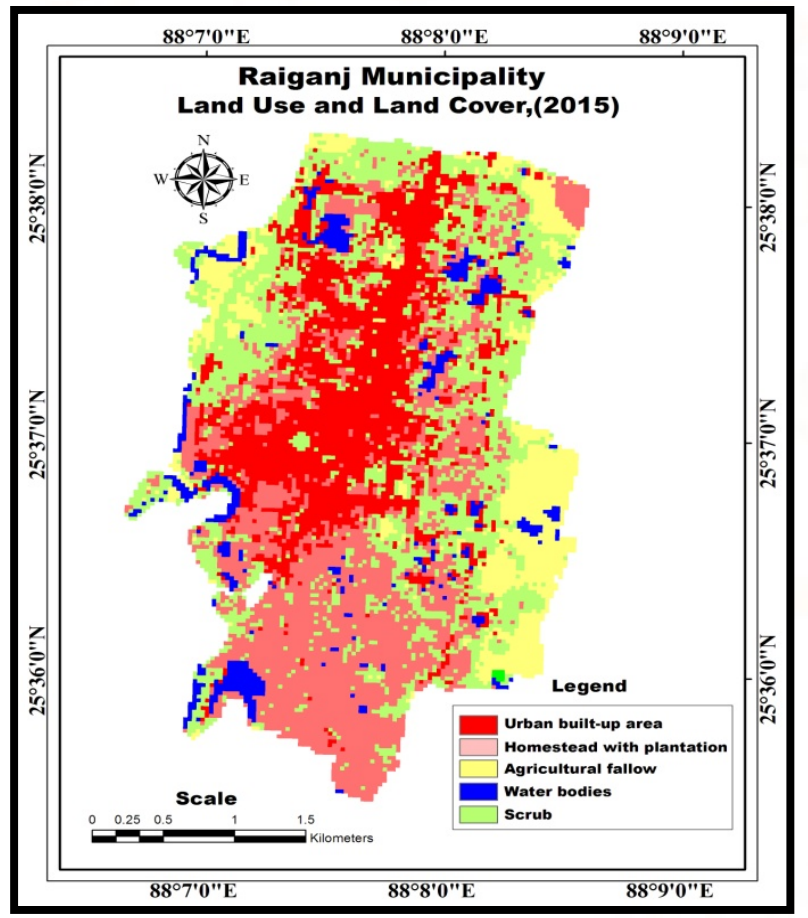

Source: Based on Landsat 5 (2015) image

LULC maps from Landsat-5 image of 1991 and 2005 were produced and to compare the LULC trend analysis within this municipality was carried out. 
Table: 3

Change Detection Statistics: 1991-2015

\begin{tabular}{|c|c|c|c|c|c|c|}
\hline \multirow[t]{2}{*}{ Land use land cover category } & \multicolumn{2}{|c|}{1991} & \multicolumn{2}{|c|}{2015} & \multicolumn{2}{|c|}{$\begin{array}{c}\text { change } \\
1991-2015\end{array}$} \\
\hline & $\mathrm{Sq} \mathrm{Km}$ & $\%$ & $\mathrm{Sq} \mathbf{K m}$ & $\%$ & $\mathrm{Sq} \mathbf{K m}$ & $\%$ \\
\hline Built up area & 1.45 & 13.48 & 2.66 & 24.72 & 1.21 & 11.24 \\
\hline Home street with plantation & 3.01 & 27.97 & 3.3 & 30.66 & 0.29 & 2.69 \\
\hline Agricultural fallow & 2.36 & 21.93 & 1.21 & 11.25 & -1.15 & -10.68 \\
\hline Water bodies & 0.77 & 7.16 & 0.46 & 4.28 & -0.31 & -2.88 \\
\hline Scrubs & 3.17 & 29.46 & 3.13 & 29.09 & -0.04 & -0.37 \\
\hline Total & 10.76 & 100 & 10.76 & 100 & $\mathbf{0}$ & $\mathbf{0}$ \\
\hline
\end{tabular}

Figure 3: Change in LULC 1991-2015
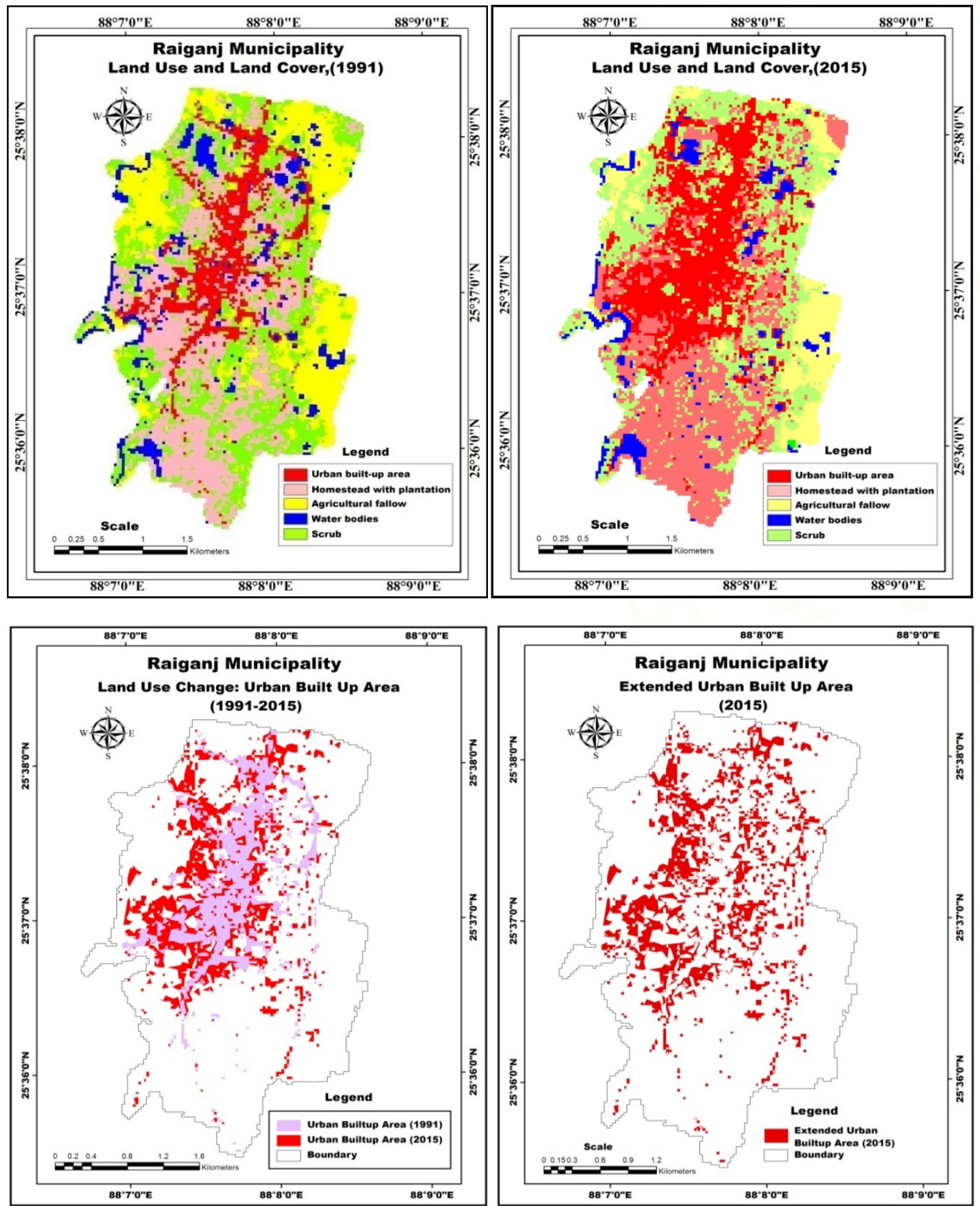


\section{Source: Based on Landsat-5 images(1991 and 2015)}

Table:4

\section{Show the criteria,suitability score and weightage for disposal site selection}

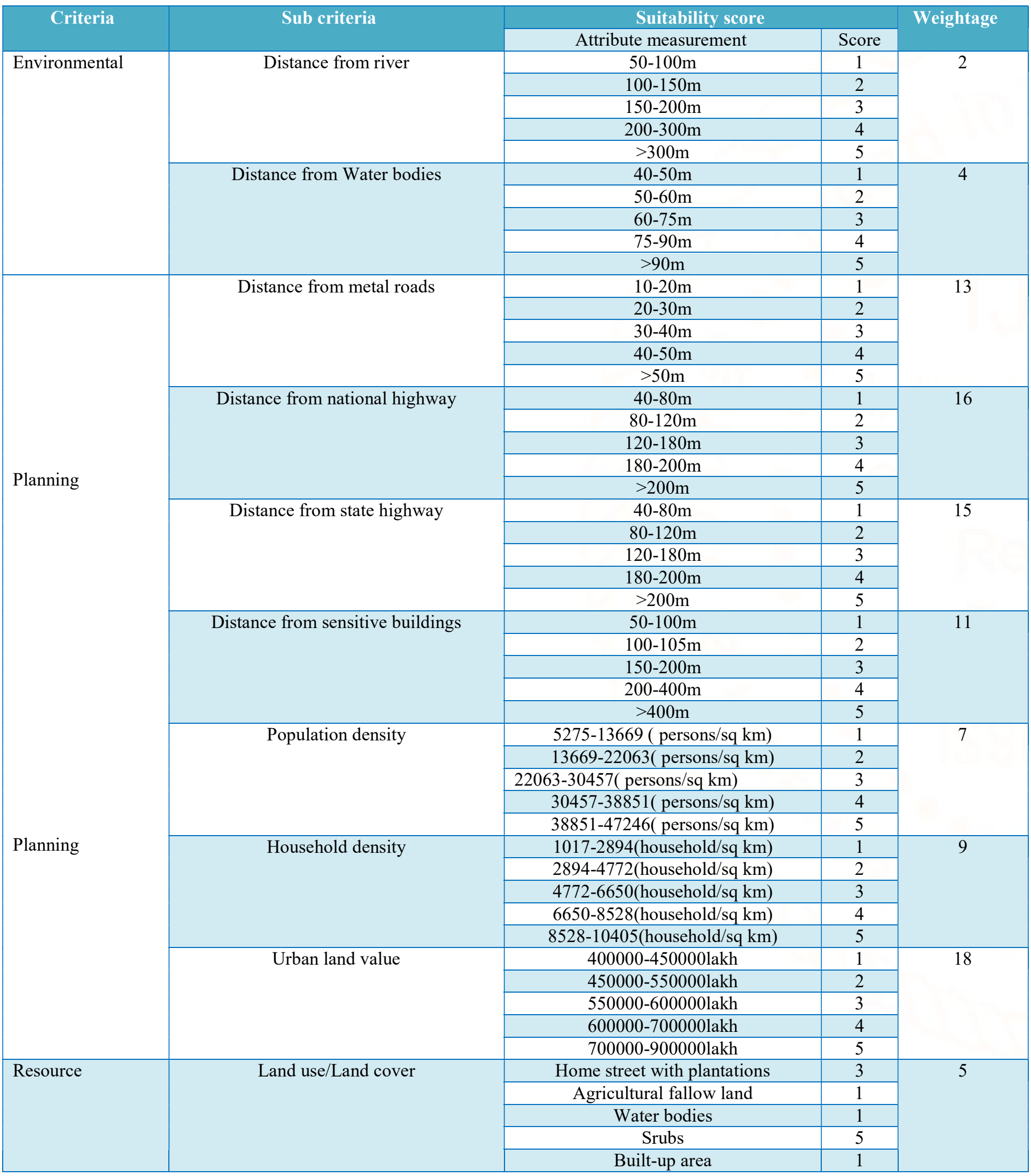


Shows the criterion maps of Raiganj municipality for suitable disposal site selection

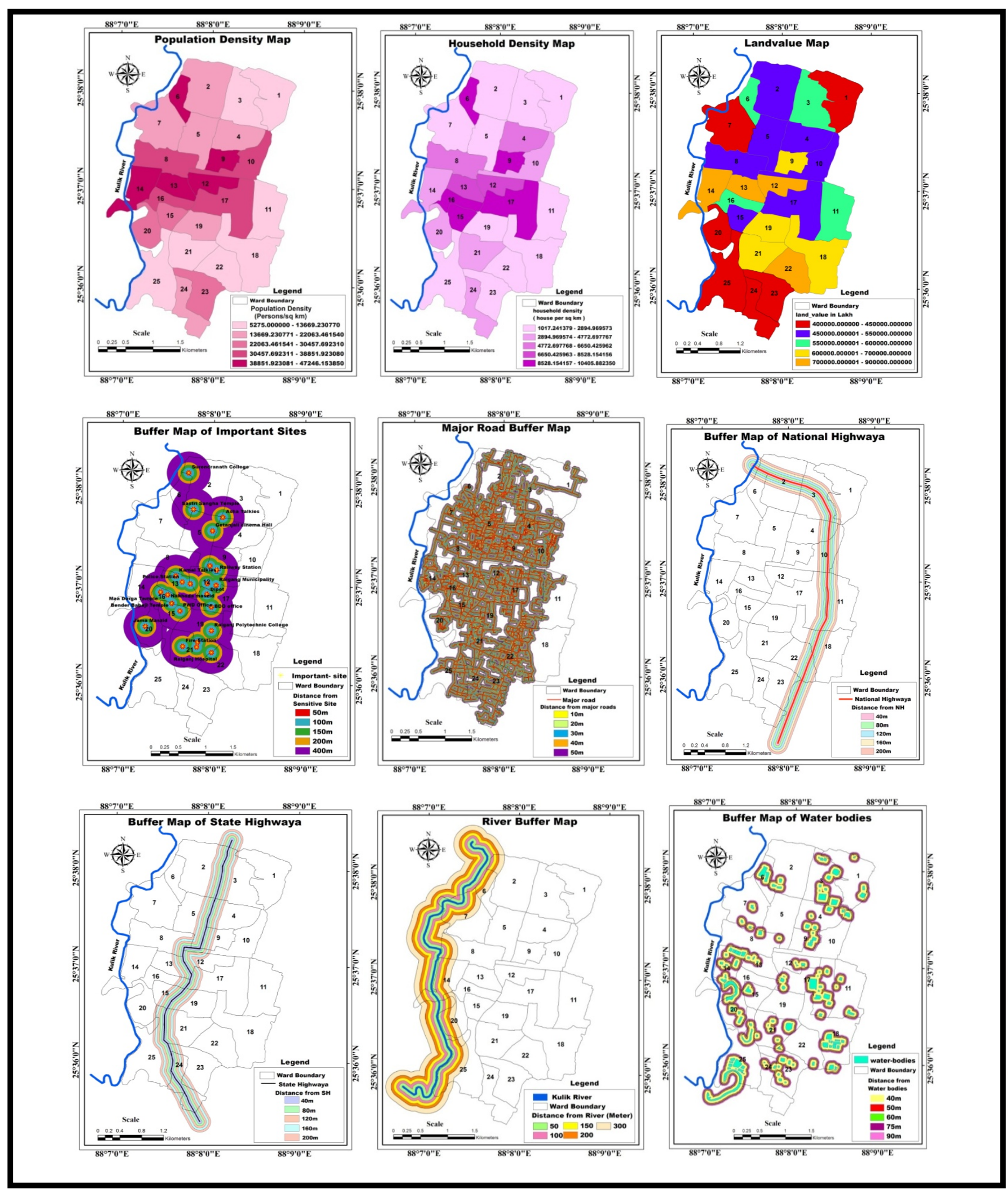




\section{CONCLUSION:}

In this present study the application of Geographical information systems and Remote sensing data were used to identify a suitable disposal site for Raiganj Municipality. This study mainly used the multicriteria overlay analysis method. From the MCDSS analysis result shows that $0.09 \%$ area is highly suitable, $0.61 \%$ area is moderately suitable and $0.17 \%$ of area is less suitable (as shows in figure-4). In Raiganj municipality most suitable locations are found in ward no 6 which fulfill the all criteria of highly suitable site. Accordingly the appropriate site which was might be suitable from environmental, planning and resource point of view.

Table: 5

\section{Degree of suitability}

\begin{tabular}{|c|c|c|c|c|}
\hline \multirow[t]{2}{*}{ Criteria } & \multirow{2}{*}{$\begin{array}{c}\text { Sub } \\
\text { criteria }\end{array}$} & \multicolumn{3}{|c|}{ Degree of suitability } \\
\hline & & $\begin{array}{l}\text { Highest } \\
\text { suitable }\end{array}$ & $\begin{array}{l}\text { Moderate } \\
\text { suitable }\end{array}$ & $\begin{array}{c}\text { Less } \\
\text { suitable }\end{array}$ \\
\hline \multirow[t]{2}{*}{$\begin{array}{c}\text { Environm } \\
\text { ental }\end{array}$} & $\begin{array}{l}\text { Distance } \\
\text { from river }\end{array}$ & $>200 \mathrm{~m}$ & $100-200 \mathrm{~m}$ & $0-100 \mathrm{~m}$ \\
\hline & $\begin{array}{l}\text { Distance } \\
\text { from } \\
\text { water- } \\
\text { bodies }\end{array}$ & $>75 \mathrm{~m}$ & $50-75 \mathrm{~m}$ & $0-50 \mathrm{~m}$ \\
\hline \multirow[t]{7}{*}{ Planning } & $\begin{array}{l}\text { Distance } \\
\text { from metal } \\
\text { roads }\end{array}$ & $>40 \mathrm{~m}$ & $20-40 m$ & $0-20 \mathrm{~m}$ \\
\hline & $\begin{array}{l}\text { Distance } \\
\text { from } \\
\text { national } \\
\text { highway }\end{array}$ & $>160 \mathrm{~m}$ & $80-160 m$ & $0-80 \mathrm{~m}$ \\
\hline & $\begin{array}{l}\text { Distance } \\
\text { from state } \\
\text { highway }\end{array}$ & $>160 \mathrm{~m}$ & $80-160 \mathrm{~m}$ & $0-80 \mathrm{~m}$ \\
\hline & $\begin{array}{l}\text { Distance } \\
\text { from } \\
\text { sensitive } \\
\text { buildings }\end{array}$ & $>160 \mathrm{~m}$ & $80-160 \mathrm{~m}$ & $0-80 \mathrm{~m}$ \\
\hline & $\begin{array}{l}\text { Urban land } \\
\text { value }\end{array}$ & $\begin{array}{c}\text { Rs. } 400000- \\
600000\end{array}$ & $\begin{array}{l}\text { Rs.600000- } \\
800000\end{array}$ & $\begin{array}{c}\text { Rs. }>8000 \\
00\end{array}$ \\
\hline & $\begin{array}{c}\text { Population } \\
\text { density }\end{array}$ & $\begin{array}{c}5275- \\
22063 \\
\text { (persons/sq } \\
\mathrm{km} \text { ) }\end{array}$ & $\begin{array}{c}22063- \\
38851 \\
\text { (persons/sq } \\
\text { km) }\end{array}$ & $\begin{array}{c}>38851 \\
\text { (persons/ } \\
\text { sq km) }\end{array}$ \\
\hline & $\begin{array}{c}\text { Household } \\
\text { density }\end{array}$ & $\begin{array}{c}1017-4772 \\
\text { (houses/sq } \\
\mathrm{km} \text { ) }\end{array}$ & $\begin{array}{c}4772-8528 \\
\text { (houses/sq } \\
\mathrm{km} \text { ) }\end{array}$ & $\begin{array}{c}>8528 \\
\text { (houses/s } \\
\text { q km) }\end{array}$ \\
\hline $\begin{array}{c}\text { Resource } \\
\text { s }\end{array}$ & Land use & Scrubs & $\begin{array}{l}\text { Agricultural } \\
\text { land }\end{array}$ & $\begin{array}{l}\text { Built-up } \\
\text { area }\end{array}$ \\
\hline
\end{tabular}

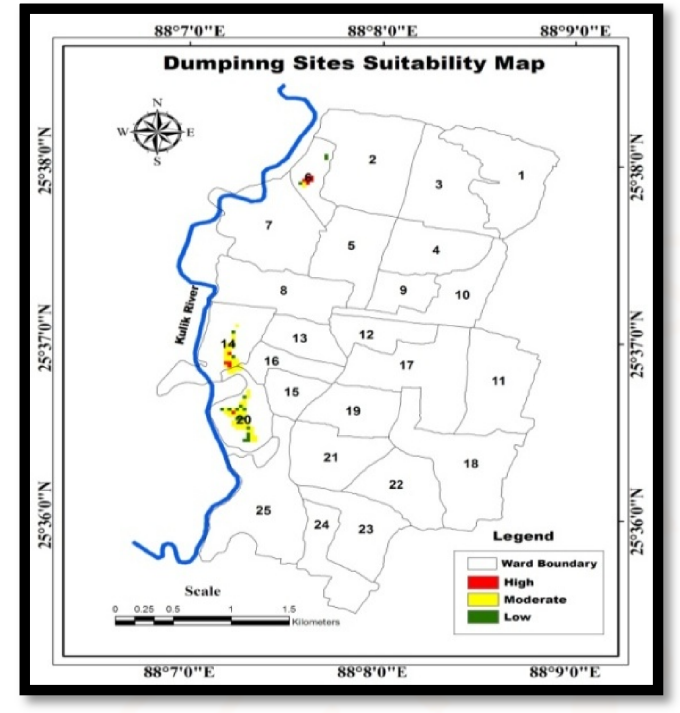

Figure 4: Suitable waste disposal site of Raiganj municipality

\section{ACKNOWLEDGEMENT:}

I am very grateful to assistant prof. Kabita lepcha, Department of geography, University of Gourbanga, for her precious guidance in bringing this paper to the present form. My special thank goes to my brother Rantadip Ray for providing technical support and also thankful to Staff of Raiganj municipality for giving me valuable information to conduct this study.

\section{REFERENCE:}

1) Chen, J. (2014). GIS-based multi-criteria analysis for land use suitability assessment in City of Regia. Environmental Systems Research , 1-10.

2) CPCB, C. P. (2012). Status report on Municipal solid waste management. New Delhi: CPCB.

3) Dungdung, A., \& Gurjar, E. (2012). Solid waste: management and related health hazards--an Indian perspective. In M. Bhatt, \& A. Illiyan, Solid waste management An indian perspective (p. PP 155). New Delhi: Synergy books of India.

4) Ekmekcioglu, M., Kaya, T., \& Kahraman, C. (2010). Fuzzy multicriteria disposal method and site selection for municipalsolid waste mannagement. Waste Management, 1729-1736.

5) Gidde, P., Todkar, P. D., \& Kokate, P. (2008). Municipal Solid Waste Management in Emerging Mega Cities : A case study of Pune city. Indo Italian Conference on Green and Clean Environment (pp. pp. 441-449). Pune: MAEER's MIT College of Engineering. 
6) Gorsevisky, P. V., Donevska, K. R., Mitrovski, C. D., \& Frizado, J. P. (2011). Integrating multicriteria evalution techniques with geographic information systems for landfill site selection: A case study using ordered weighted average. Waste Management 32 , 287-296.

7) Guerrero, L. A., Mass, G., \& Hogland, W. (2012). Solid waste management challenges for cities in developing countries. Waste management 33 , 220-232.

8) Jaybbhaye, R., Mundhe, N., \& Dorik, B. (2014). Site Suitability for Urban Solid Waste Disposal Using Geoinformatics: A Casse Study of Pune Municipal Corporation,Maharashtra, India. International Journal for Advanced Remote sensing and GIS, 769-783.

9) Medina, M. (2002). Municipal solid waste management in the third world cities: Lessons learned and a proposal for improvement. Human settlement develpment, Vol.III, 1-19.

10) Minghua, Z., Xiumin, F., Rovetta, A., Qichang, H., Vicentini, F., \& Bingkai, L. (2009). Municipal solid waste management in Pudong new area, China. Waste management 29 , 1227-1233.

11) Mohammedshum, A., Gebresilassie, M., Rulinda, C., Kahsay, G., \& Tesfay, M. (2014). Application of Geographical Information System And Remotesensing in Effective Solid Waste Disposal Site Selection in Wukro Town Tigray, Ethiopia. The International Archives of the Photogrammetry, Remote Sensing and Spatial Information Sciences , 115-119.

12) Pamnani, A., \& Srinivasarao, M. (2014). Municipal solid waste management in India: A review and some new results. International journal of civil engineering and technology (IJCIET) , 01-08.

13) Paul, S. (2012). Location Allocation for Urban Waste Disposal Site Using Multi-Criteria Analysis: A study on Nabadwip Municipality, West Bengal, India. International Journal of Geomatics and Geosciences, 74-87.

14) Rathi, S. (2006). Alternative approaches for better municipal solid waste management in Mumbai. Journal of Waste Management 26(10) , 11921200.

15) Rathor, K., Khan, T., \& Verma, P. (2010). A comparative study of sustainability of solid waste management in selected Indian cities with emphasis on cost recovery. The Ecoscan 4(4), 333-337.

16) Sahu, S., Nair, D. j., \& Sharma, P. K. (2014). Review on Solid Waste Management Practice in India: A State of Art. International Journal of Innovative Research \& Development, Vol-3 (Issue-3), 261-264.

17) Sener, S., Sener, E., \& Karaguzel, R. (2010). Solid aste disposal site selection with GIS and AHP methodology: a case study in SenirkentUiuborlu0(Isparta)Basin,Turkey. Environmental Monitoring and Assessment, 533-554.

18) Sharholy, M., Ahmad, K., Mahmood, G., \& Trivedi, R. (2008). Municipal solid waste management in Indian cities - A review. Waste Management 28, 459-467.

19) Siddiqui, J., Pandey, D. G., \& Akhtar, D. S. (2013). A Case Study of Solid Waste Management in Mysore City. International Journal of Application or Innovation in Engineering \& Management (IJAIEM) , Vol-2 (Issue-11), 290294.

20) Singh, A. K., \& Gupta, V. (2012). Management of Solid Waste \& Its Effects on Health: A Case Study of South Delhi. In M. Bhatt, \& A. Illiyan, Solid Waste Management An Indian Perspective ( pp. 177-192). New Delhi: Synergy Book India.

21) Srivastava, R., \& Srivastava, A. (2012). Municipal Solid Waste Management: A Case Study of "The City Of Taj". In M. Bhatt, \& A. Illiyan, Solid Waste Management An Indian Perspective (pp. 239-240). New Delhi: Synergy Book India.

22) Suresh, B., \& Sivasankar, S. (2014). Identification of suitable site for urban solid waste disposal using GIS and remote sensing techniques. Acase stuudy of Virudhunagar municipality, Indiia. International Journal of Geomatics and Geosciences, 320-331. 